\title{
Wave train model for knickpoint migration
}

\author{
Nicolas Loget ${ }^{a, b, ~}{ }^{*}$, and Jean Van Den Driessche ${ }^{c}$ \\ ${ }^{a}$ Collège de France, Chaire de Géodynamique, Europôle de l'Arbois, 13545 Aix-en-Provence, France \\ ${ }^{\mathrm{b}}$ IFREMER-French Research Institute for Exploitation of the sea, DRO/GM, Technopôle Brest-Iroise, Bp 70, \\ 29280 Plouzané, France \\ ${ }^{c}$ Géosciences Rennes, Université de Rennes 1, UMR 6118, Campus de Beaulieu, 35042 Rennes cedex, France \\ *: Corresponding author : N. Loget, email address : nicolas.loget@univ-nantes.fr
}

\begin{abstract}
:
Rivers respond to a drop in their base level by incising the topography. The upstream propagation of an incision, as usually depicted by a knickpoint migration, is thought to depend on several parameters such as the drainage area, lithology, and the amplitude of the base level drop. We first investigate the case of the Messinian Salinity Crisis that was characterized by the extreme base level fall $(1500 \mathrm{~m})$ of the Mediterranean Sea at the end of the Miocene. The response of drainage areas of three orders of magnitude $\left(10^{3}\right.$ to $\left.10^{6} \mathrm{~km}^{2}\right)$ highlights the dominant role of the drainage area (with a square root relationship) in controlling the knickpoint migration after a base level fall. A compilation of mean rates of knickpoint propagation for time durations ranging from $10^{2}$ to $10^{7}$ years displays a similar relationship indicating that successive wave trains of knickpoint can migrate in a river: first, wave trains linked to the release of the alluvial cover and then, wave trains related to the bedrock incision, which correspond to the real time response of rivers. Wave trains with very low retreat rates (long lived knickpoints $>1 \mathrm{My}$ ) rather correspond to the response time of regional landscape.
\end{abstract}

Keywords: Knickpoint; Migration rate; Wave train; Messinian Salinity Crisis; Base-level drop 


\section{Introduction}

The rate of drainage network response to a lowering of its base level is poorly documented in natural settings due to the transient nature of the potential markers of such event (terraces, knickpoints, landslides...). What governs this response is also subject to debate (see Crosby and Whipple, 2006 and references herein). The migration rate of knickpoints is a first approximation of the rate at which a network can return to equilibrium after a base level drop. It has been assimilated to a kinematic wave that progresses from downstream to upstream (e.g. Rosenbloom and Anderson, 1994; Whipple and Tucker, 1999; Bishop et al., 2005; Wobus et al., 2006). Rates of knickpoint migration generally range between 0.001 and $0.1 \mathrm{~m} \mathrm{y}^{-1}$ (e.g. Van Heijst and Postma, 2001) with exceptional values greater than $1 \mathrm{~m} \mathrm{y}^{-1}$ as for the Niagara Falls or for active orogens (Philbrick, 1970; Tinkler et al., 1994; Wohl, 1998; Crosby and Whipple, 2006). Several field and experimental studies have emphasized the correlation that exists between the rate of knickpoint migration and the upstream drainage area, which is considered as a proxy for water discharge (Parker, 1977; Schumm et al., 1987; Rosenbloom and Anderson, 1994; Bishop et al., 2005; Crosby and Whipple, 2006; Loget et al., 2006; Berlin and Anderson, 2007). Others have stressed the role of rock strength and transported sediments (e.g. Sklar and Dietrich, 1998; Stock and Montgomery, 1999; Hayakawa and Matsukura, 2003; Snyder et al., 2003; Tucker, 2004; Crosby and Whipple, 2006; Gasparini et al., 2006; Hayakawa et al. 2008).

The migration rate is determined from the ratio between (i) the length between the current position of the knickpoint and the supposed position of the initial knickpoint; and (ii) the time spent between these two positions. Due to the sparse data available to restore the past longitudinal profile and the initial vertical position of the knickpoint, it is almost impossible to know if the current position of the knickpoint is the result of the retreat of one wave train or the composite results of many wave trains (Fig. 1).

Here we examine this issue by looking at a major base level lowering (around 1500m) that occurred in the Mediterranean region during the Messinian Salinity Crisis (e.g. Hsü et al., 1973) in the late of Miocene. This base level drop triggered the incision of rivers that were flowing into the Mediterranean at that time (e.g. Hsü et al., 1973). It provides the opportunity to investigate a wave train of knickpoint migration after a large base level fall in the case (i) of a large range of drainage areas $\left(10^{3}\right.$ to $3.10^{6} \mathrm{~km}$ ); (ii) for a lacking time window (around 100 $\mathrm{Ky}$ ) compared to long-lived knickpoints (1's My) or latest knickpoints (10's Ky) and (iii) for a different climate because these incisions were "frozen" by Pliocene sedimentation after the reflooding of the Mediterranean. We then compare our results with other knickpoint migration rates in the frame of a general wave train model for the migration of knickpoints during geological time.

\section{The Messinian Mediterranean sea level drop}

The closure of the gateways between the Atlantic Ocean and the Mediterranean Sea at the end of the Miocene (c.a. 5.9 Ma, Gautier et al., 1994; Krijgsmann et al. 1999) induced a sea level fall of about $1500 \mathrm{~m}$ (Hsü et al., 1973; Clauzon et al., 1996). This so-called Messinian Salinity Crisis (MSC) resulted in the deposition of up to $2000 \mathrm{~m}$ of evaporites in the desiccated Mediterranean basin (Hsü et al., 1973). The sea level fall was also responsible for major incision of the pre-MSC drainage network, resulting in the formation of deep canyons (Hsü et al., 1973; Barber, 1981; Clauzon, 1982). This Late Miocene base level fall has long been known through the investigation of canyon infilling by Pliocene sediments along the French Mediterranean coast (Depéret, 1895; Baulig, 1928). The sudden reflooding of the Mediterranean during the early Pliocene (e.g. Loget and Van Den Driessche, 2006) caused the very rapid rise in sea level of up to $80 \mathrm{~m}$ above the present sea level and the en masse deposition of the suspended load of the Messinian rivers in Gilbert deltas (e.g., 
Clauzon et al., 1995). These deposits inhibited the erosion of rivers and consequently the morphology of the Messinian canyons is largely preserved. The Messinian event is the only example of the record of knickpoint migration under climatic conditions different than today, with a well constrained time duration of erosional phase (90 000 and 300000 years) (Gautier et al, 1994; Clauzon et al., 1996; Krijgsman et al., 1999).

\section{Messinian knickpoints versus current drainage areas}

Physical modeling shows that, for a given time duration shorter than the time necessary to recover river profile equilibrium, the distance of headward rejuvenation $(H R)$ that developed after a base level lowering is related to the pre-existing drainage area (Parker, 1977; Schumm et al., 1987). We therefore suspect that the HR that developed during the MSC $(H R m)$ was related to the pre-MSC drainage areas as already suggested by Baulig (1928). We make the a priori assumption that the pre-MSC drainage areas were similar to the present-day drainage areas, an assumption that is sustained by regional studies. Firstly, the Messinian incisions are located within, or very near, to the present-day valleys. Secondly, according to Griffin (2002), the river Nile fed the Mediterranean at the end of the Miocene with a drainage basin of about $2.10^{6} \mathrm{~km}^{2}$. The upstream part of the Nile drainage dates from the Oligocene (Pik et al., 2003). The Rhone started to drain the Western Alps toward the Mediterranean from the end of the Tortonian (Ballesio, 1972; Mandier, 1988; Sissingh, 2001) whereas the Durance drained the Southern Alps before the MSC (Ballesio, 1972). Regional slopes that shaped the drainage of the Languedoc rivers (Orb, Hérault) were established during the Middle and Late Miocene (Langhian to Messinian) (e.g. Séranne et al., 2002). The French Pyrenean rivers (Tech and Têt Rivers) flowed into the Mediterranean by the upper Miocene (Clauzon et al., 1987). This continuity of drainage lines means that most of the preserved Messinian incisions are observable within the current valleys around the Mediterranean.

As mentioned above, the $H R m$ have only been partly preserved, so a determination of the whole incision length is not straightforward, especially for the largest drainage areas, i.e., the Rhone and the Nile drainage areas $\left(10^{5}\right.$ and $3.10^{6} \mathrm{~km}^{2}$, respectively) (Figs. 2 and 3, Table 1$)$. Hereafter, $H R m$ have been first estimated from the occurrence of the transition from marine to continental Pliocene sedimentary fills. For example, in the Rhone valley, the Messinian vertical incision reaches about $300 \mathrm{~m}$ at Lyon, i.e., $300 \mathrm{~km}$ from the present-day coastline. The $H R m$ propagates most probably northwards, following the current Bresse depression up to $200 \mathrm{~km}$ north of Lyon (total $H R m$ of $500 \mathrm{~km}$ ) where a slight incision still occurs and marks the northernmost propagation of the Messinian Rhone response (Baumard, 2001). In the Nile valley, a Messinian vertical incision of nearly $80 \mathrm{~m}$ has been identified at Aswan, $1000 \mathrm{~km}$ from the present coastline (Chumakov, 1973). By extending the Messinian palaeo-slope of the Nile, Chumakov (1973) estimated $H R m$ at $2000 \mathrm{~km}$.

For smaller drainage areas $\left(10^{3}\right.$ to $\left.10^{4} \mathrm{~km}^{2}\right) \mathrm{HRm}$ has been deduced from the progressive upstream thinning of the sedimentary Pliocene fills of the paleovalleys. For example, in the Orb valley, $H R m$ is considered to be about $35 \mathrm{~km}$ upstream of the present-day coastline where Pliocene filling or Messinian erosional surfaces disappear (Ambert et al., 1998). This layout was found in most valleys of the South of France (Hérault, Tech, Têt, Var, and Durance) (Clauzon, 1978; 1979; Clauzon et al., 1987; Ambert et al., 1998).

The plot of $H R m$ versus the present-day catchment area $(A)$ provides the following relation (Fig. 4):

$$
H R m=\alpha A^{\mathrm{h}} \text { with } 0.64<\alpha<1.3 \text { and } 0.45<\mathrm{h}<0.55 \text { (Equation 1) }
$$

This relation shows that the upstream propagation of the Messinian incision was controlled by the size of the pre-MSC drainage areas. 
Upstream positions of $H R m$ correspond to knickpoints from which we have deduced mean rates of migration ranging from 0.1 to $1 \mathrm{~m} \mathrm{y}^{-1}$ for the drainage areas ranging from $10^{3}$ to $10^{4}$ $\mathrm{km}^{2}$, respectively (Table 1 ). Knickpoint migration rates reach 2.65 to $10 \mathrm{~m} \mathrm{y}^{-1}$ for the Rhone and Nile drainage areas, respectively (Table 1). Translating equation (1) into knickpoint migration rates $(V)$ provides a similar relationship such as:

$$
V=C A^{h} \text { (Equation 2) }
$$

where $C$ is a coefficient of retreat efficiency $\left(L^{(1-2 h)} T^{-1}\right)$. This relationship is of the same form as that between the propagation rate of incision and the upstream drainage area described in other works (e.g., Parker, 1977; Bishop et al., 2005; Crosby and Whipple, 2006; Berlin and Anderson, 2007). This relationship is often compared to a celerity wave equation with regard to knickpoint propagation and is the consequence of the stream power law (e.g. Rosenbloom and Anderson, 1994; Whipple and Tucker, 1999). As the exponent $\mathrm{h}$ is approximately 0.5, the equation 2 can be written:

$$
V=C A^{0.5} \text { (Equation 3) }
$$

where $C$ is a coefficient independent of the size of the system $\left(\mathrm{T}^{-1}\right)$ with a value around $10^{-5} \mathrm{y}^{-}$ ${ }^{1}$ (Fig. 5). From these relationships follow two important regional implications:

Firstly, considering that the Messinian incisions have developed in different basement lithologies ranging from sedimentary rocks to metamorphic or plutonic rocks, and through various basement tectonic structures as well (Table 1), the previous relationships imply that the upstream drainage area is the predominant parameter on knickpoint migration, with regard to lithology. This fact was already advanced in other studies (e.g. Bishop and Cowell, 1997; Bishop et al., 2005; Berlin and Anderson, 2007). Secondly, such a correspondence between Messinian knickpoints and current drainage areas necessarily implies a correspondence between current drainage areas and Messinian drainage areas. Consequently, this relationship could be a good test in order to track the drainage basins whose extent has potentially varied since the end of the Miocene in Mediterranean (Loget et al., 2005; Babault et al., 2006), due in particular to regional deformation induced by the convergence between the African and European plates.

\section{Comparison with other studies of knickpoint migration rates}

Figure 5 compares the Messinian event with other examples of knickpoint migrations whose rates range between 0.001 and $1000 \mathrm{~m} \mathrm{y}^{-1}$ for drainage areas between $10^{-2}$ and $10^{7} \mathrm{~km}^{2}$, concerning bedrock rivers, alluvial rivers or gullies and for various amplitudes of base level falls (Fig. 5 and Table 2). By arranging these rates according to their respective time scales, four trends appear on the plot and can be fitted with similar celerity wave equations, i.e. with a exponent $b$ equal to 0.5 , but with a different coefficient of retreat efficiency $C$ ranging from $10^{-2} \mathrm{y}^{-1}$ to $10^{-7} \mathrm{y}^{-1}$ (Fig. 5). We interpret the relative scattering of knickpoint data in bedrock (points 7 to 20 ) between $10^{4}$ years and $10^{5}$ years as due to the vicinity of the hillslopechannel transition or to the existence of a threshold drainage area for knickpoint retreat. Below this critical area, which is considered to be in the order of $\sim 10^{\circ} \mathrm{km}^{2}$ (e.g. Montgomery and Foufoula-Georgiou, 1993; Lague and Davy, 2003; Crosby and Whipple, 2006), data interpretation cannot rely on stream power relationship or its derivative (equation 3), but must take into consideration hillslope or colluvial erosional processes.

The lowest $C$ value $\left(10^{-2} \mathrm{y}^{-1}\right)$ corresponds to alluvial rivers, and all other $C$ values are related to bedrock rivers or dominantly bedrock rivers (Table 2 ). The lower the $C$ value, the greater the time scale of observation.

The presence of these four trends in the plot may be interpreted in two ways.

(1) Depending on the geological time, knickpoint migration rates vary so that the longer the time duration, the lower the migration rate. This might result from more or less long term variations in climate and/or tectonics. Except for the MSC, the compiled data are based on 
present-day position of knickpoints, and therefore all the observed systems have suffered minimum common geological history. If we suspect an influence of global climate change, all the data plotted are concerned. The kind of major geological process over the last million years that could have produced major variations in intrinsic knickpoint migration processes remains elusive.

(2) The decrease in the $C$ value with the respective increase in the timescale of observation corresponds to a dilatation effect. In other words, we may wonder, in the Messinian example, what the required time duration, and therefore the respective value of $C$, would have been for knickpoints to reach the upstream part of the catchments.

To test this possible time dilatation effect, we derive Equation 3. We introduce some Hack components (Hack, 1957; Montgomery and Dietrich, 1992) so that Equation 3 can be written

$L_{T} \approx a A^{0.5} \quad$ (Equation 4)

with $L_{T}$ the length of the initial river and a the Hack exponent and each increment of time (corresponding to $1 / C$ ) is therefore:

$\frac{\Delta H R}{\Delta t}=C \frac{L_{T}}{a}$ (Equation 5)

For each increment of time $\mathrm{N}$, we obtain:

$\Delta H R_{N}=\frac{(a-1)^{(N-1)}}{a^{N}} L_{T}$ (Equation 6)

Results are compiled on figure 6 for the case of the Messinian Rhone where 10 time increments (i.e. about $1 \mathrm{Ma}$ ) are required for a knickpoint to reach the upstream part of the catchment. This corresponds to a maximum decrease in $C$ by one order of magnitude, i.e. a $C$ value of $10^{-6} \mathrm{y}^{-1}$.

The highest $C$ value obtained for alluvial rivers $\left(10^{-2} \mathrm{y}^{-1}\right)$ compared to the second highest value for bedrock rivers $\left(10^{-4} \mathrm{y}^{-1}\right)$ is too far to be explained by a time dilatation effect. The easy erodibility of the low cohesive rocks of the alluvial or soil cover compared to the strength of the rather highly cohesive rocks encountered in bedrock rivers is most probably the origin of this difference in $C$ values.

The $10^{-4} \mathrm{y}^{-1}$ and $10^{-5} \mathrm{y}^{-1} \mathrm{C}$ values are close enough to be interpreted by a dilatation effect if we introduced the one order of magnitude of confidence calculated. Moreover, the climate during the Messinian around the Mediterranean is known to have been much drier than at present (e.g. Suc and Bessais, 1990). Consequently, the power of streams was likely to have been restrained, compared to the present ones, and consequently, the capacity of knickpoints to propagate, was also reduced.

The $10^{-7} \mathrm{y}^{-1} \mathrm{C}$ value cannot be explained by a time dilatation effect and its explanation is not straightforward because under recent periods and for a same drainage area some knickpoints have propagated very fast and others very slowly.

However, two clarifications must be made as to the method used to calculate rates of knickpoint migration. Firstly, the age of a knickpoint is generally determined by the age of the geological event that produced the base level variation, which triggers the knickpoint migration. Therefore some time lag between these events cannot be excluded. Secondly, the initial altitude of the channel upstream of the observed knickpoint must have been preserved (Fig. 1). The most reliable case is "pure knickpoint retreat" (Gardner, 1983). Reconstructions of paleo-profiles from interfluves (e.g. Seidl et al., 1994), recent measurements above waterfalls (e.g. Haviv et al., 2006) as well as recent knickpoint retreat modelling (Frankel et al., 2007) show that erosion always occurs upstream of a knickpoint making the above assumption very doubtful. Figure 1 shows how a knickpoint in a current river may correspond either to one wave of knickpoint migration or to several waves of knickpoint migration.

According to our results (Fig. 5), the first wave propagation of knickpoints in bedrock occurred between $10^{4}$ to $10^{6}$ years depending on climate. On the other hand, a later wave propagation $\left(>10^{6}\right.$ years) of knickpoints may correspond to reasons other than climate. The data set that composes the $C 10^{-7} \mathrm{y}^{-1}$ value belongs to very low relief topography (plateau or 
uplifting margin), or volcanic regions with highly porous bedrocks, that supposes an inefficient drainage zone above the knickpoint. Consequently, the knickpoint propagates while the landscape and regional slope develops. In this case, the apparent rate of knickpoint migration corresponds not so much to the response time of rivers as to the response time of the regional landscape after a base level drop.

\section{Conclusion}

The rate of knickpoint migration can be used as a proxy for the time necessary to return toward equilibrium after a base-level drop or tectonic event. According to the Messinian example, the rate of knickpoint migration is basically controlled by the upstream drainage area such as $V=C A^{0.5}$, where $V$ is the rate of knickpoint migration, $A$ the upstream drainage area and $C$ a coefficient independent of the size of the system. Our synthesis, that encompasses different knickpoint retreat rates at various scales of space and time, leads us to extend this interpretation whatever (1) climate, (2) geological context (3) alluvial or bedrock nature of rivers.

- For a same drainage area, the rate of knickpoint migration is two orders of magnitude higher in alluvial rivers than in bedrock rivers;

- Climate can be responsible for a difference of one order of magnitude in the rate of knickpoint migration in bedrock rivers;

- A time scale dilatation effect cannot be excluded in migration rate values due to (i) a possible time lag between the respective ages of a knickpoint and the triggering base level drop and (ii) erosion upstream of knickpoints;

- Very low mean rates of knickpoint migration in bedrock rivers are apparent and are should be related to the response time that is required by erosional processes as a whole (river, hillslope, weathering) to shape the landscape on the regional scale.

Finally we suggest that after a base level drop, the return to equilibrium of the perturbed longitudinal profile of rivers is achieved by successive upstream wave trains of knickpoints: first, wave train that induce the release of alluvial cover, then wave train that drive bedrock incision, which correspond to the real-time response of rivers $\left(\sim 10^{4-5}\right.$ years depending on climate). Wave train with very low retreat rates (long-lived knickpoints $>1$ My) rather corresponds to the response time of regional landscape.

\section{Acknowledgements}

We thank two anonymous referees and Editor Takashi Oguchi for their constructive remarks. We are grateful to Peter Van Der Beek and Paul Bishop for comments of an earlier version. We are indebted to Alison Chalm who greatly improved the English. Special thanks to Sébastien Castelltort, Julien Babault, Michel Choroszynski and Marion Van Den Driessche for fruitful discussions at different stages of this work. Financial support was provided by Centre National de la Recherche Scientifique INSU "Programme Relief de la Terre" and "Programme Eclipse". 
Ambert, P., Aguilar, J.P., Michaux, J., 1998. Evolution géodynamique messiniopliocène en Languedoc central : le paléo-réseau hydrographique de l'Orb et de l'Hérault (sud de la France). Geodinamica Acta 11 (2-3), 139-146. doi:10.1016/S0985-3111(98)80010-7

Babault, J., Loget, N., Van Den Driessche, J., Castelltort, S., Bonnet, S., Davy, P., 2006. Did the Ebro basin connect to the Mediterranean before the Messinian salinity crisis? Geomorphology 81 (1-2), 155-165. doi:10.1016/j.geomorph.2006.04.004

Ballesio, R., 1972. Etude stratigraphique du Pliocène rhodanien. Document du laboratoire de géologie de la Faculté des Sciences de Lyon 53, 333 pp.

Barber, P.M., 1981. Messinian subaerial erosion of the Proto-Nile delta. Marine Geology 44 (3-4), 253-272.doi:10.1016/0025-3227(81)90053-0

Baulig, 1928. Le Plateau central de la France et sa bordure méditerranéenne. Thesis, Paris, $591 \mathrm{pp}$.

Baumard, B., 2001. Valorisation de données pour l'étude de la crise messinienne dans le Gard rhodanien et la moitié est de la France. PhD Thesis, Ecole des Mines de Paris, 260 pp.

Berlin, M.M., Anderson, R.S., 2007. Modeling of knickpoint retreat on the Roan Plateau, western Colorado. Journal of Geophysical Research 112, F03S06. doi:10.1029/2006JF000553.

Betts, H.D., DeRose, R.C., 1999. Digital elevation models as a tool for monitoring and measuring gully erosion. Journal of Applied Earth Observation and Geoinformation 1, 91101.

Bishop, P., Cowell, P., 1997. Lithological and drainage network determinants of the character of drowned, embayed coastlines. Journal of Geology 105, 685-699.

Bishop, P., Hoey, T.B., Jansen, J.D., Artza, I.L., 2005. Knickpoint recession rate and catchment area: the case of uplifted rivers in eastern Scotland. Earth Surface Processes and Landforms 30, 767-778. doi:10.1002/esp.1191

Brocard, G.Y., Van der Beek, P.A., Bourles, D.L., Siame, L.L., Mugnier, J.L., 2003. Long-term fluvial incision rates and postglacial river relaxation time in the French Western Alps from 10Be dating of alluvial terraces with assessment of inheritance, soil development and wind ablation effects. Earth and Planetary Science Letters 209 (1-2), 197-214. doi:10.1016/S0012-821X(03)00031-1

Chumakov, I.S., 1973. Pliocene and Pleistocene deposits of the Nile valley in Nubia and upper Egypt: in Initial reports of the Deep Sea Drilling Project, v.13: Washington, D. C., U. S. Government Printing Office, pp. 1242-1243.

Clauzon, G., 1978. The Messinian Var canyon (Provence, Southern France). Paleogeographic implications. Marine Geology 27, 231-246. doi:10.1016/00253227(78)90033-6

Clauzon, G., 1979. Le canyon messinien de la Durance (Provence, France): une preuve paléogéographique du bassin profond de dessication. Palaeogeography, Palaeoclimatology, Palaeoecology 29, 15-40. doi:10.1016/0031-0182(79)90073-7

Clauzon, G., 1982. Le canyon messinien du Rhône: une preuve décisive du "dessicated deep basin model" (Hsü, Cita et Ryan, 1973). Bulletin de la Société Géologique de France 24, 231-246.

Clauzon, G., Aguilar, J.P., Michaux, J., 1987. Le bassin pliocene du Roussillon (Pyrenees-Orientales, France): exemple $d^{\prime}$ evolution geodynamique $d^{\prime}$ une ria mediterraneenne consecutive a la crise de salinite messinienne. Comptes-Rendus de l'Académie des Sciences de Paris 304 (11), 585-590.

Clauzon, G., Rubino, J.L. Savoye, B., 1995. Marine Pliocene Gilbert-type fan deltas along the French Mediterranean coast. A typical infill feature of preexisting subaerial Messinian canyons: In: IAS-16th Regional Meeting of Sedimentology, Field Trip Guide Book, ASF Ed., Paris, v. 23, pp. 145-222. 
Clauzon, G., Suc, J.P., Gautier, F., Berger, A., Loutre, M.F., 1996. Alternate interpretation of the Messinian salinity crisis: Controversy resoved? Geology 24 (4), 363366. doi :10.1130/0091-7613(1996)024<0363:AIOTMS>2.3.CO;2

Crosby, B.T., Whipple, K.X., 2006. Knickpoint Initiation and Distribution within Fluvial Networks: 236 waterfalls in the Waipaoa River, North Island, New Zealand. Geomorphology 82 (1-2), 16-38. doi:10.1016/j.geomorph.2005.08.023

Depéret, C., 1895. Aperçu sur la structure générale et l'histoire de la formation de la vallée du Rhône. Annales de Géographie 4, 432-452.

Farías, M., Charrier, R., Carretier, S., Martinod, J., Fock, A., Campbell, D., Cáceres, J., Comte, D., 2008. Late Miocene high and rapid surface uplift and its erosional response in the Andes of central Chile $\left(33^{\circ}-35^{\circ} \mathrm{S}\right)$. Tectonics 27, TC1005. doi:10.1029/2006TC002046.

Frankel, K.L., Pazzaglia, F.J., Vaughn, J.D., 2007. Knickpoint evolution in a vertically bedded substrate, upstream-dipping terraces, and Atlantic slope bedrock channels. Geological Society of America Bulletin 119 (3), 476-486. doi: 10.1130/B25965.1

Gardner, T.W., 1983. Experimental study of knickpoint and longitudinal profile evolution in cohesive, homogeneous material. Geological society of America Bulletin 94 (5), 664-672. doi: 10.1130/0016-7606(1983)94<664:ESOKAL>2.0.CO;2

Gasparini, N.M., Bras, R.L., Whipple, K.X., 2006. Numerical modeling of non-steady-state river profile evolution using a sediment-flux-dependent incision model, in Tectonics, climate and landscape evolution, S. Willett, N. Hovius, M. Brandon \& D. Fisher, eds., GSA Special Paper 398, pp 127-141. doi: 10.1130/2006.2398(08)

Gautier, F., Clauzon, G., Suc, J.P., Cravatte, J., Violanti, D., 1994. Age et durée de la crise de salinité messinienne. Comptes-Rendus de l'Académie des Sciences de Paris 318 (II), 1103-1109.

Griffin, D.L., 2002. Aridity and humidity: two aspects of the late Miocene climate of North Africa and the Mediterranean. Palaeogeography, Palaeoclimatology, Palaeoecology 182 (1-2), 65-91. doi:10.1016/S0031-0182(01)00453-9

Hack, J.T., 1957. Studies of longitudinal stream profiles in Virginia and Maryland. U.S. Geological Survey Professional Paper 294 (B), 45-94.

Hassan, M.A., Klein, M.U., 2002. Fluvial adjustment of the Lower Jordan River to a drop in the Dead Sea level. Geomorphology 45 (1-2), 21-33. doi:10.1016/S0169555X(01)00187-8

Haviv, I., Enzel, Y., Whipple, K.X., Zilberman, E., Stone, J., Matmon, A., Fifield, L.K., 2006. Amplified erosion above waterfalls and oversteepened bedrock reaches. Journal of Geophysical Research 111, F04004, doi:10.1029/2006JF000461.

Hayakawa, Y., Matsukura, Y., 2003. Recession rates of waterfalls in Boso peninsula, Japan, and a predictive equation. Earth Surface Processes and Landforms 28 (6), 675-684. doi: 10.1002/esp.519

Hayakawa, Y. S., Obanawa, H., Matsukura, Y., 2008. Post-volcanic erosion rates of Shomyo falls in Tateyama, Central Japan. Geografiska Annaler, 90A (1), 65-74. doi: 10.1111/j.14680459.2008.00334.x

Hsü, K.J., Cita, M.B., Ryan, W.B.F., 1973. The origin of the Mediterranean evaporites: in Initial reports of the deep sea drilling project, v.13: Washington, D. C., U. S. Government Printing Office, p. 1203-1231.

Krijgsman, W., Hilgen, F.J., Raffi, I., Sierro, F.J., Wilson, D.S., 1999. Chronology, causes and progression of the Messinian salinity crisis. Nature 400, 652-655. doi:10.1038/23231

Lague, D., Davy, P., 2003. Constraints on the long-term colluvial erosion law by analyzing slope-area relationships at various tectonic uplift rates in the Siwaliks hills (Nepal). Journal of Geophysical Research 108 (B2), 2129, doi:10.1029/2002JB001893

Loget, N., Van Den Driessche, J., 2006. On the origin of the Strait of Gibraltar. Sedimentary Geology 188-189, 341-356. doi:10.1016/j.sedgeo.2006.03.012

Loget, N., Van Den Driessche, J., Davy, P., 2005. How did the Messinian Salinity Crisis end? Terra Nova 5, 414-419. doi:10.1111/j.1365-3121.2005.00627.x 
Loget, N., Davy, P., Van Den Driessche, J., 2006. Mesoscale fluvial erosion parameters deduced from modeling the Mediterranean sea level drop during the Messinian (late Miocene). Journal of Geophysical Research 111, F03005. doi:10.1029/2005JF000387.

Mandier, P., 1988. Le relief de la moyenne vallée du Rhône au Tertiaire et au Quaternaire. Essai de synthèse paléogéographique. Document BRGM 151.

Montgomery, D.R., Dietrich, W.E., 1992. Channel initiation and the problem of landscape scale. Science 255, 826-830. doi: 10.1126/science.255.5046.826

Montgomery, D.R., Foufoula-Georgiou, E., 1993. Channel network source representation using digital elevation models. Water Resources Research 29 (12), 39253934.

Parker, R.S., 1977. Experimental study of basin evolution and its hydrologic implications. Unpublished PhD dissertation, Colorado State University, Fort Collins, 331 pp.

Pazzaglia, F.P., Gardner, T.W., Merrits, D.J., 1998. Bedrock Fluvial incision and longitudinal profile development over geologic time scales determined by fluvial terraces, in Tinkler, K. J., and Wohl, E. E., eds., Rivers over rock: fluvial processes in bedrock channels. American Geophysical Union Geophysical Monograph 107, pp. 207-235.

Philbrick, S.S., 1970. Horizontal Configuration and the Rate of Erosion of Niagara Falls. Geological society of America Bulletin 81 (12), 3723-3732. doi: 10.1130/00167606(1970)81[3723:HCATRO]2.0.CO;2

Pik, R., Marty, B., Carignan, J., Lavé, J., 2003. Stability of the Upper Nile drainage network (Ethiopia) deduced from (U-Th)/He thermochronometry: implications for uplift and erosion of the Afar plume dome. Earth and Planetary Science Letters 215 (1-2), 73-88. doi:10.1016/S0012-821X(03)00457-6

Rosenbloom, N.A., Anderson, R.S., 1994. Hillslope and channel evolution in a marine terraced landscape, Santa Cruz, California. Journal of Geophysical Research 99 (B7), 14,013-14,029.

Séranne, M., Camus, H., Lucazeau, F., Barbarand, J., Quinif, Y., 2002. Surrection et érosion polyphasées de la bordure cévenole. Un exemple de morphogenèse lente. Bulletin de la Société Géologique de France 173 (2), 97-112. doi:10.2113/173.2.97

Schumm, S.A., Mosley, M.P., Weaver, W.E, 1987. Experimental fluvial geomorphology. John Wiley and Sons, New York, 413 pp.

Seidl, M.A., Dietrich, W.E., Kirchner, J.W., 1994. Longitudinal profile development into bedrock: An analysis of Hawaiian channels. Journal of Geology 102, 457-474.

Sissingh, W., 2001. Tectonostratigraphy of the West Alpine foreland: correlation of Tertiary sedimentary sequences, changes in eustatic sea-level and stress regimes. Tectonophysics 333 (3-4), 361-400.doi:10.1016/S0040-1951(01)00020-8

Sklar, L., Dietrich, W. E., 1998. River longitudinal profiles and bedrock incision models: stream power and the influence of sediment supply, in Tinkler, K. J., and Wohl, E. E., eds., Rivers over rock: fluvial processes in bedrock channels: American Geophysical Union Geophysical Monograph 107, pp. 237-260.

Snyder, N. P., Whipple, K.X., Tucker, G.E., Merritts, D.J., 2003. Channel response to tectonic forcing: field analysis of stream morphology and hydrology in the Mendocino triple junction region, northern California. Geomorphology 53 (1-2), 97-127. doi:10.1016/S0169$555 \times(02) 00349-5$

Stock, J.D., Montgomery, D.R., 1999. Geologic constraints on bedrock river incision using the stream power law. Journal of Geophysical Research 104 (B3), 4983-4993. doi: 10.1029/98JB02139

Suc, J.P., Bessais, E., 1990. Pérennité d'un climat thermo-xérique en Sicile avant, pendant, après la crise de salinité messinienne. Comptes-Rendus de l'Académie des Sciences de Paris 310 (2), 1701-1707.

Tinkler, K.J., Pengelly, J.W., Asselin, G., Parkins, W.G., 1994. Postglacial Recession of Niagara Falls in Relation to the Great Lakes. Quaternary Research 42 (1), 20-29. doi:10.1006/qres.1994.1050 
Tomkins, K.M., Hesse, P.P., 2004. Evidence of Late Cenozoic uplift and climate change in the stratigraphy of the Macquarie River Valley, New South Wales. Australian Journal of Earth Sciences 51 (2), 273-290. doi:10.1111/j.1440-0952.2004.01057.x

Tucker, G.E., 2004. Drainage basin sensitivity to tectonic and climatic forcing: implications of a stochastic model for the role of entrainment and erosion thresholds. Earth Surface Processes and Landforms 29 (2), 185-205. doi:10.1002/esp.1020

Van Heijst, M.W.I.M., Postma, G., 2001. Fluvial response to sea level changes: a quantitative analogue, experimental approach. Basin Research 13 (3), 269-292. doi: 10.1046/j.1365-2117.2001.00149.x

Whipple, K.X., Tucker, G.E., 1999. Dynamics of the stream-power river incision model: Implications for height limits of mountain ranges, landscape response timescales, and research needs. Journal of Geophysical Research 104 (B8), 17661-17674.

Wobus, C. W., Crosby, B.T., Whipple, K.X., 2006. Hanging valleys in fluvial systems: Controls on occurrence and implications for landscape evolution, Journal of Geophysical Research 111, F02017, doi:10.1029/2005JF000406.

Wohl, E. E. 1998. Bedrock channel morphology in relation to erosional processes, in Tinkler, K. J., and Wohl, E. E., eds., Rivers over rock: fluvial processes in bedrock channels: American Geophysical Union Geophysical Monograph 107, pp. 133-151.

Young, R.W., McDougall, I., 1993. Long-term landscape evolution: Early Miocene and modern rivers in southern New South Wales, Australia. Journal of Geology 101 (1), 35-49. 


\section{Figures}

Figure 1

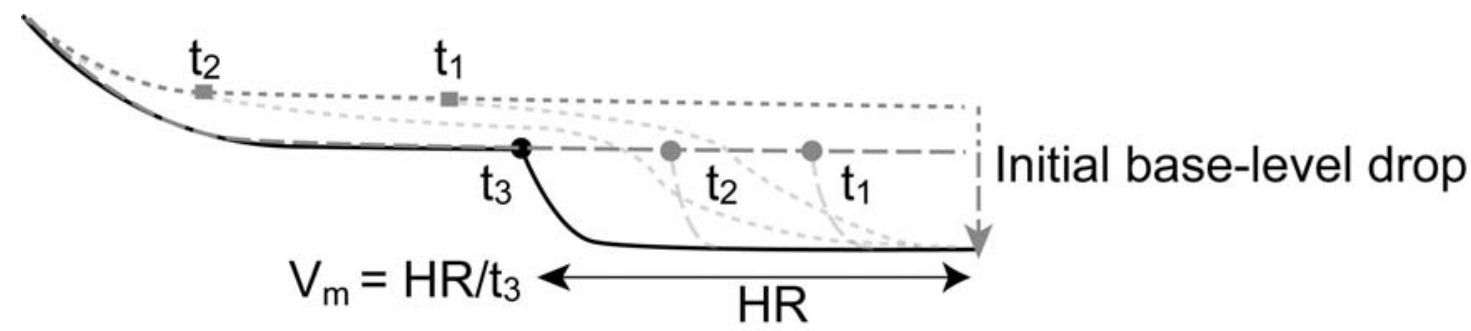

Figure 1

Differents meanings of the mean rate of a knickpoint retreat on a river profile. Starting from a finite state for the calculation of a knickpoint retreat at time $t_{3}$, the mean rate $(\mathrm{Vm})$ is calculated by dividing the headward propagation of the knickpoint $(H R)$ by the time $\left(\mathrm{t}_{3}\right)$. If the initial base-level corresponds to the upstream graded part of the knickpoint position of the river (dashed case) with intermediate positions at $t_{1}$ and $t_{2}$ (grey circles), this suggests that the retreat is the result of the way of one wave train. If the initial base-level is upper than the upstream graded part of the knickpoint position of the river (dotted case) with intermediate positions at $t_{1}$ and $t_{2}$ (grey squares), this suggests that the retreat is the result of the way of two successive wave trains, the first one having already reached the head of the river. 


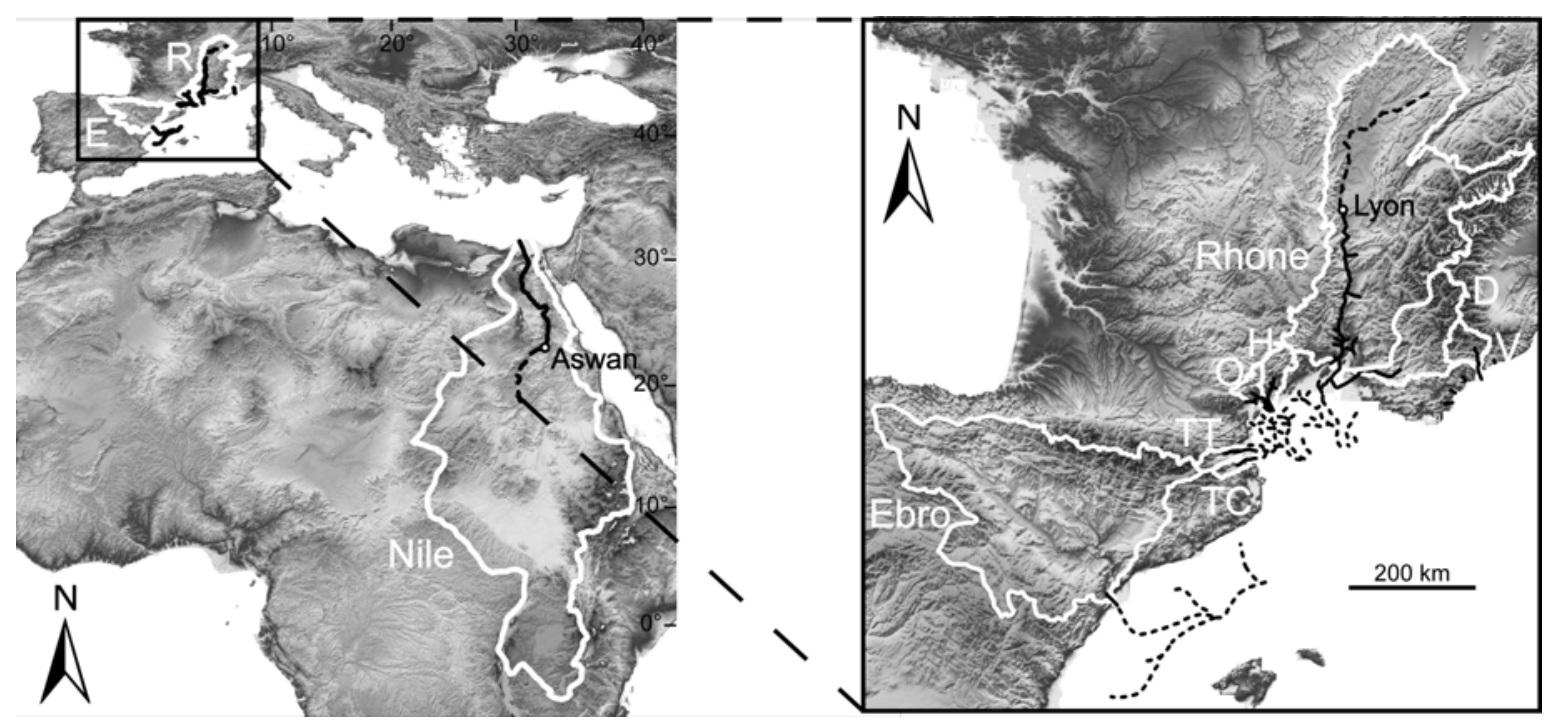

Figure 2

Digital Elevation Model showing the Messinian incisions and the corresponding current drainage areas (source: GTOPO30).

Thick black lines-Onshore incisions; Dotted black lines-Offshore incisions; Dashed black lines-Possible maximum extension.

D-Durance ; E-Ebro ; O-Orb ; H-Herault ; R-Rhone ; TC-Tech ; TT-Tet ; V-Var.

Figure 3

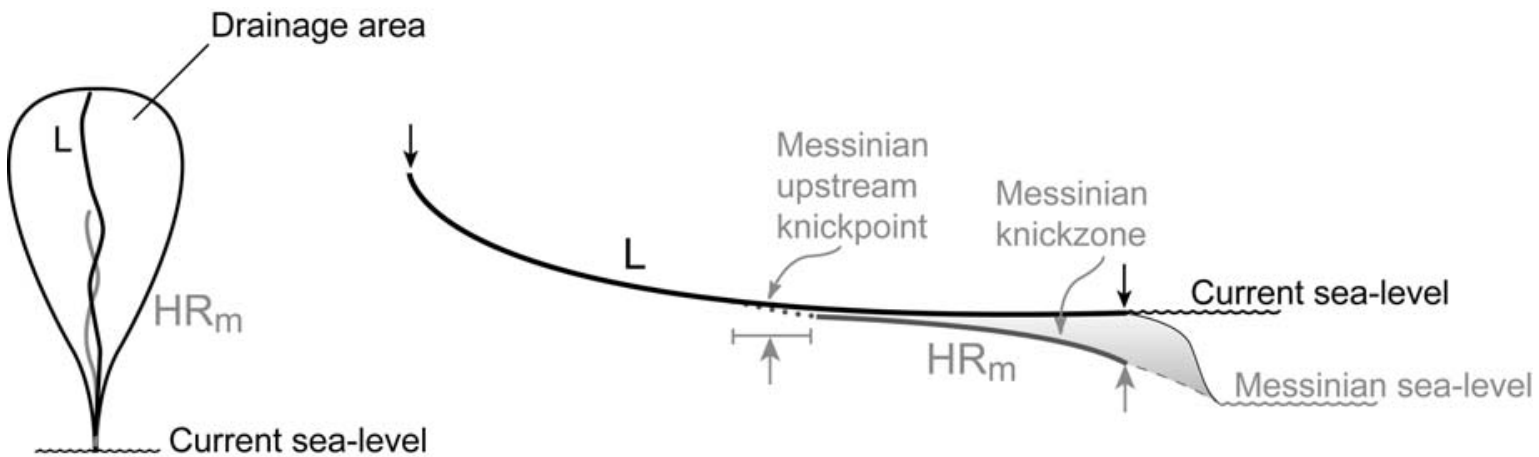

Figure 3

Method for determining the distance of headward rejuvenation during the Messinian $(H R m)$ and the length of the current river $(\mathrm{L})$ versus the current drainage area. 
Figure 4

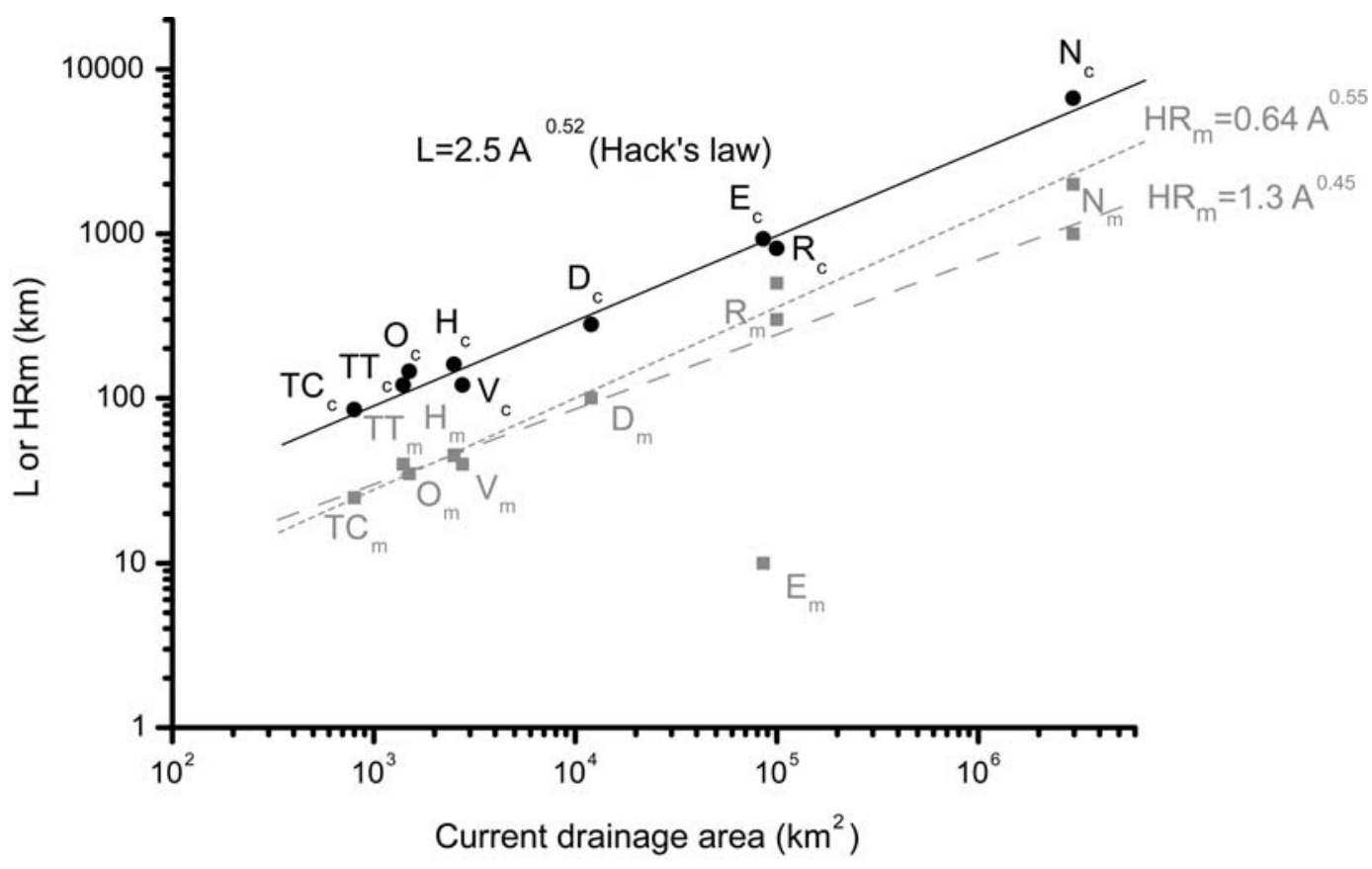

Figure 4

Black (thick and dashed): Lengths of the Messinian incisions (measured from the present coast line) versus the corresponding present-day drainage areas (see text for further explanation)

Grey: the current river lengths versus their respective drainage areas.

Index $\mathrm{c}$ and $\mathrm{m}$ refer to the current rivers and the Messinian incisions respectively.

D-Durance ; E-Ebro ; O-Orb ; H-Herault ; N- Nile; R-Rhone ; TC-Tech ; TT-Tet ; V-Var.

Figure 5 


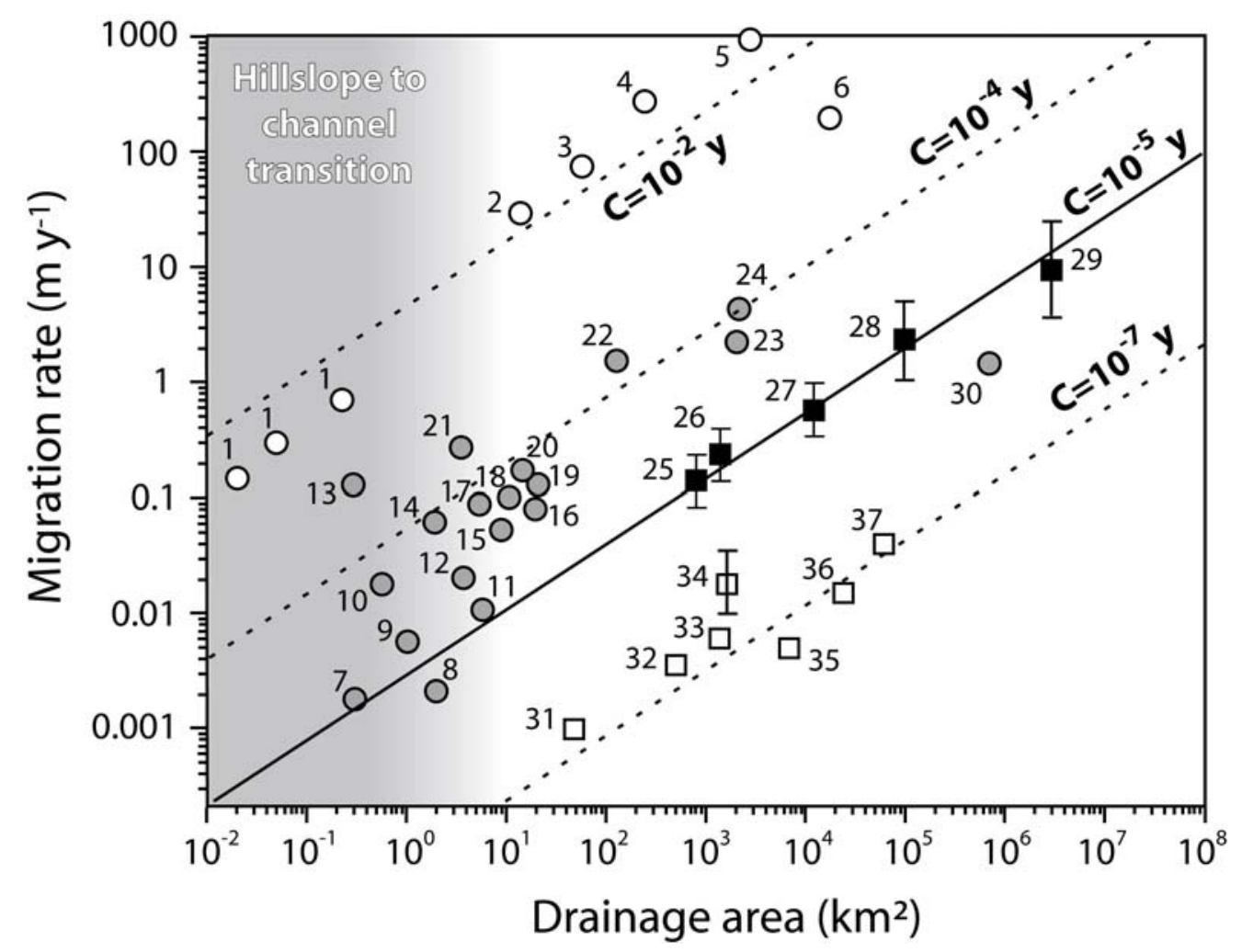

Figure 5

Average migration rates of incision versus drainage areas. Four domains can be determined with regards to the time scale $\left(10^{1} \mathrm{yrs}\right.$ : white circle; $10^{2}-10^{4} \mathrm{yrs}$ : grey circle; $10^{5}-10^{6} \mathrm{yrs}$ : black square; $10^{6}-10^{7}$ : white square) which boundaries correspond to the equation $V=C A^{0.5}$ 1- Waipaoa gullies (Betts and Derose, 1999); 2- St Catherine creek tributarie (Yodis and Kesel, 1993); 3- Homochitto river tributarie (Yodis and Kesel, 1993); 4- St Catherine creek, Mississippi basin (Yodis and Kesel, 1993); 5- Homochitto river, Mississippi basin (Yodis and Kesel, 1993); 6- Jordan river (Hassan and Klein, 2002); 7- Ryogenji falls (Hayakawa and Matsukura, 2003); 8- Darn Bay (Bishop et al., 2005); 9- Strathlethan Bay (Bishop et al., 2005); 10- Fukasawa-no Falls (Hayakawa and Matsukura, 2003); 11- Bilsdean Burn (Bishop et al., 2005); 12- Glasslin Burn (Bishop et al., 2005); 13- Soho falls (Hayakawa and Matsukura, 2003); 14- Oikawa-fudo falls (Hayakawa and Matsukura, 2003); 15- Milldown Burn (Bishop et al., 2005); 16- Denfinella (Bishop et al., 2005); 17- Abbey Burn (Bishop et al., 2005); 18- Zenzen falls (Hayakawa and Matsukura, 2003); 19- Catterline Burn (Bishop et al., 2005); 20- Afuri falls (Hayakawa and Matsukura, 2003); 21- Sanagowa falls (Hayakawa and Matsukura, 2003); 22- Bervie Water (Bishop et al., 2005); 23- Drac river (Brocard et al., 2003); 24- Waipaoa river (Crosby and Whipple, 2006); 25- Tech river (this study); 26- Tech river (this study); 27- Durance river (this study); 28- Rhone river (this study); 29- Nile river (this study); 30- Niagara falls (Wohl, 1998); 31- Kauhao river (Seidl et al., 1994); 32Parachute creek (Berlin and Anderson, 2007); 33- Roan creek (Berlin and Anderson, 2007); 34- Tinguiririca river (Farias et al., 2008); 35- Shoalhaven river (Young and McDougall, 1993); 36- Macquarie river (Tomkins and Hesse, 2004); 37- Susquehanna river (Pazzaglia et al., 1998) 
Figure 6

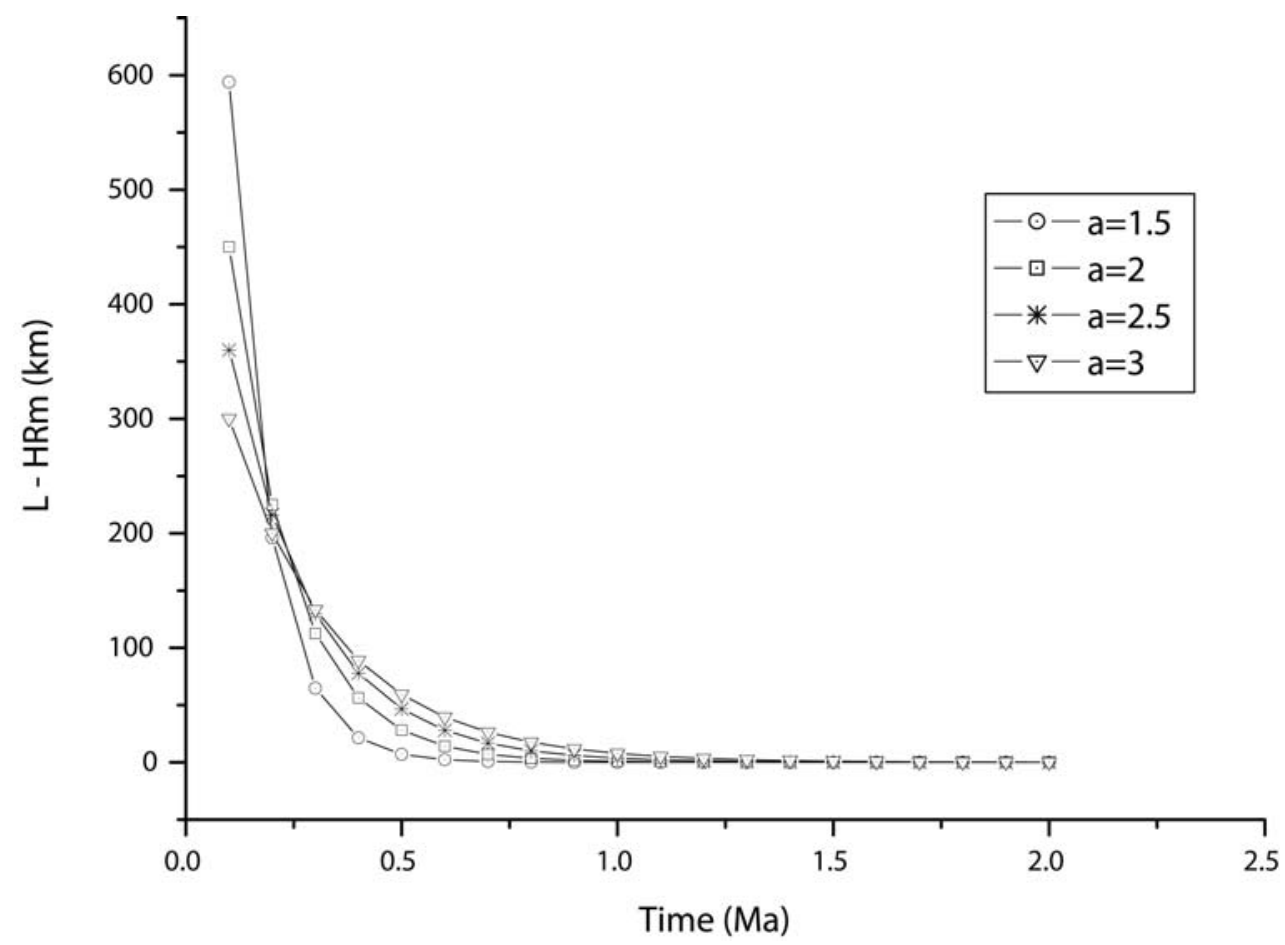

Figure 6

Analytical solution of Equation 6 describing the propagation of the Messinian knickpoint in the Rhone river according to a celerity equation type (Equation 3) for different Hack exponent (a). At each increment of time, the propagation is shown as the difference between the assumed length of the Messinian Rhone $\left(\mathrm{L}_{T}=900 \mathrm{~km}\right)$ and the headward propagation of the Messinian knickpoint $(H R m)$ corresponding to the non-incised upstream part of the river. 
Table 1

\begin{tabular}{|c|c|c|c|c|c|c|}
\hline River & $\begin{array}{r}\text { Current } \\
\text { Drainage } \\
\text { area } \\
{\left[\mathrm{km}^{2}\right]} \\
\end{array}$ & $\begin{array}{r}\text { Current Length } \\
{[\mathrm{km}]}\end{array}$ & $\begin{array}{c}\text { Lengths of } \\
\text { messinian incisions } \\
\text { from the current } \\
\text { shoreline }[\mathrm{km}] \\
\end{array}$ & $\begin{array}{r}\text { Migration } \\
\text { rate } \\
{\left[\mathrm{my}^{-1}\right]}\end{array}$ & Lithology & References \\
\hline Nile & 2960000 & 6671 & $\begin{array}{r}1000 \\
2000\end{array}$ & $\begin{array}{l}3.3-10 \\
6.6-20\end{array}$ & $\begin{array}{r}\text { Sedimentary rocks, } \\
\text { Granitic rocks }\end{array}$ & $\begin{array}{r}\text { Chumakov, } 1973 \\
\text { Barber, } 1981\end{array}$ \\
\hline Rhone & 99000 & 812 & $\begin{array}{l}300 \\
500\end{array}$ & $\begin{array}{r}1-3 \\
1.6-5\end{array}$ & $\begin{array}{r}\text { Sedimentary rocks } \\
\text { (sanstone, limestone), } \\
\text { Grantic rocks }\end{array}$ & $\begin{array}{r}\text { Clauzon, } 1982 \\
\text { Mandier, } 1988 \\
\text { Baumard, } 2001\end{array}$ \\
\hline Ebro & 85820 & 930 & 10 & $0.033-0.1$ & $\begin{array}{r}\text { Granitic rocks, } \\
\text { Metamorphic rocks }\end{array}$ & $\begin{array}{r}\text { Maestro et al., } \\
2002\end{array}$ \\
\hline Durance & 12000 & 280 & 100 & $0.33-1$ & $\begin{array}{r}\text { Sedimentary rocks } \\
\text { (sanstone, limestone) }\end{array}$ & Clauzon, 1979 \\
\hline Var & 2758 & 120 & 40 & $0.13-0.4$ & $\begin{array}{r}\text { Sedimentary rocks } \\
\text { (sanstone, limestone) }\end{array}$ & $\begin{array}{r}\text { Clauzon, } 1978 \\
\text { Irr, } 1984\end{array}$ \\
\hline Herault & 2500 & 160 & 45 & $0.15-0.45$ & $\begin{array}{r}\text { Sedimentary rocks } \\
\text { (sanstone, limestone) }\end{array}$ & Ambert, 1998 \\
\hline Orb & 1758 & 145 & 35 & $0.12-0.35$ & $\begin{array}{r}\text { Sedimentary rocks } \\
\text { (sanstone, limestone) }\end{array}$ & $\begin{array}{r}\text { Clauzon et al., } \\
1995 \\
\text { Ambert, } 1998\end{array}$ \\
\hline Tech & 1400 & 120 & 25 & $0.08-0.25$ & $\begin{array}{r}\text { Sedimentary rocks } \\
\text { (sanstone, limestone), } \\
\text { Grantic rocks, } \\
\text { Metamorphic rocks } \\
\text { Sedimentary rocks } \\
\text { (sanstone, limestone), } \\
\text { Grantic rocks, } \\
\text { Metamorphic rocks }\end{array}$ & $\begin{array}{r}\text { Clauzon et al., } \\
1995\end{array}$ \\
\hline
\end{tabular}

Table 1

Morphological features and geological settings of several Messinian incisions and corresponding present-day drainage basins. The two-end member migration rate values are deduced from the time range of the Messinian erosional stage (90 to $300 \mathrm{Ky}$ after Krijgsman et al., 1999 and Clauzon et al., 1996 respectively). 
Table 2

\begin{tabular}{|c|c|c|c|c|}
\hline $\begin{array}{l}\text { Location } \\
\text { knickpoint }\end{array}$ & $\begin{array}{l}\text { Knickpoint } \\
\text { retreat } \\
\left(\mathrm{my}^{-1}\right)\end{array}$ & $\begin{array}{l}\text { Drainage } \\
\text { area } \\
\left(\mathrm{km}^{2}\right)\end{array}$ & $\begin{array}{l}\text { Knickpoint } \\
\text { time scale } \\
\text { (years) }\end{array}$ & References \\
\hline Waipaoa gullie 1 & 0.15 & 0.02 & $10^{1} \sim 10^{2}$ & $\begin{array}{l}\text { Betts and Derose, } \\
1999\end{array}$ \\
\hline $\begin{array}{l}\text { New Zealand } \\
\text { Waipaoa gullie }\end{array}$ & 0.3 & 0.05 & $10^{1} \sim 10^{2}$ & Betts and Derose, \\
\hline $\begin{array}{l}2, \\
\text { New Zealand } \\
\text { Waipaoa gullie } \\
3 \text {, } \\
\text { New Zealand }\end{array}$ & 0.7 & 0.22 & $10^{1} \sim 10^{2}$ & $\begin{array}{l}\text { Betts and Derose, } \\
1999\end{array}$ \\
\hline $\begin{array}{l}\text { St Catherine } \\
\text { creek tributarie, } \\
\text { Mississippi basin }\end{array}$ & 30 & 12 & $10^{4} \sim 10^{5}$ & $\begin{array}{l}\text { Yodis and Kesel, } \\
1993\end{array}$ \\
\hline $\begin{array}{l}\text { Homochitto river } \\
\text { tributarie, } \\
\text { Mississippi basin }\end{array}$ & 80 & 60 & $10^{1} \sim 10^{2}$ & $\begin{array}{l}\text { Yodis and Kesel, } \\
1993\end{array}$ \\
\hline $\begin{array}{l}\text { St Catherine } \\
\text { creek, } \\
\text { Mississinni hasin }\end{array}$ & 300 & 264 & $10^{1} \sim 10^{2}$ & $\begin{array}{l}\text { Yodis and Kesel, } \\
1993\end{array}$ \\
\hline $\begin{array}{l}\text { Homochitto river, } \\
\text { Mississippi basin }\end{array}$ & 1000 & 3160 & $10^{1} \sim 10^{2}$ & $\begin{array}{l}\text { Yodis and Kesel, } \\
1993\end{array}$ \\
\hline $\begin{array}{l}\text { Jordan basin, } \\
\text { Jordan rift valley }\end{array}$ & 200 & 17665 & $10^{1} \sim 10^{2}$ & $\begin{array}{l}\text { Hassan and Klein, } \\
2002\end{array}$ \\
\hline $\begin{array}{l}\text { Ryogenji falls, } \\
\text { Japan }\end{array}$ & 0.0018 & 0.34 & $10^{2} \sim 10^{3}$ & $\begin{array}{l}\text { Hayakawa and } \\
\text { Matsukura, } 2003\end{array}$ \\
\hline $\begin{array}{l}\text { Fukasawa-no } \\
\text { Falls, } \\
\text { Japan }\end{array}$ & 0.018 & 0.6 & $10^{2} \sim 10^{3}$ & $\begin{array}{l}\text { Hayakawa and } \\
\text { Matsukura, } 2003\end{array}$ \\
\hline $\begin{array}{l}\text { Soho falls, } \\
\text { Japan }\end{array}$ & 0.13 & 0.29 & $10^{2} \sim 10^{3}$ & $\begin{array}{l}\text { Hayakawa and } \\
\text { Matsukura, } 2003\end{array}$ \\
\hline $\begin{array}{l}\text { Oikawa-fudo } \\
\text { falls, } \\
\text { Japan }\end{array}$ & 0.067 & 2 & $10^{2}-10^{3}$ & $\begin{array}{l}\text { Hayakawa and } \\
\text { Matsukura, } 2003\end{array}$ \\
\hline $\begin{array}{l}\text { Afuri falls, } \\
\text { Japan }\end{array}$ & 0.18 & 14 & $10^{2} \sim 10^{3}$ & $\begin{array}{l}\text { Hayakawa and } \\
\text { Matsukura, } 2003\end{array}$ \\
\hline $\begin{array}{l}\text { Sanagowa falls, } \\
\text { Japan }\end{array}$ & 0.27 & 3.6 & $10^{2} \sim 10^{3}$ & $\begin{array}{l}\text { Hayakawa and } \\
\text { Matsukura, } 2003\end{array}$ \\
\hline $\begin{array}{l}\text { Zenzen falls, } \\
\text { Japan }\end{array}$ & 0.1 & 11 & $10^{2} \sim 10^{3}$ & $\begin{array}{l}\text { Hayakawa and } \\
\text { Matsukura, } 2003\end{array}$ \\
\hline $\begin{array}{l}\text { Darn Bay, } \\
\text { Scotland }\end{array}$ & 0.002 & 2 & $10^{4} \sim 10^{5}$ & Bishop et al., 2005 \\
\hline $\begin{array}{l}\text { Strathlethan } \\
\text { Bay, }\end{array}$ & 0.0054 & 1 & $10^{4} \sim 10^{5}$ & Bishop et al., 2005 \\
\hline $\begin{array}{l}\text { Scotland } \\
\text { Bilsdean Burn, } \\
\text { Scotland }\end{array}$ & 0.01 & 6.5 & $10^{4} \sim 10^{5}$ & Bishop et al., 2005 \\
\hline $\begin{array}{l}\text { Glasslin Burn, } \\
\text { Scotland }\end{array}$ & 0.02 & 4.2 & $10^{4} \sim 10^{5}$ & Bishop et al., 2005 \\
\hline $\begin{array}{l}\text { Milldown Burn, } \\
\text { Scotland }\end{array}$ & 0.05 & 8.3 & $10^{4} \sim 10^{5}$ & Bishop et al., 2005 \\
\hline $\begin{array}{l}\text { Denfinella, } \\
\text { Scotland }\end{array}$ & 0.08 & 19.9 & $10^{4} \sim 10^{5}$ & Bishop et al., 2005 \\
\hline $\begin{array}{l}\text { Abbey Burn, } \\
\text { Scotland }\end{array}$ & 0.09 & 6.5 & $10^{4} \sim 10^{5}$ & Bishop et al., 2005 \\
\hline Catterline Burn, & 0.13 & 20.6 & $10^{4} \sim 10^{5}$ & Bishop et al., 2005 \\
\hline
\end{tabular}




\begin{tabular}{|c|c|c|c|c|}
\hline $\begin{array}{l}\text { Bervie Water, } \\
\text { Scotland }\end{array}$ & 1.53 & 128.3 & $10^{4} \sim 10^{5}$ & Bishop et al., 2005 \\
\hline $\begin{array}{l}\text { Drac river, } \\
\text { French Alps }\end{array}$ & 2.2 & 2095 & $10^{4}-10^{5}$ & $\begin{array}{l}\text { Brocard et al., } \\
2003\end{array}$ \\
\hline $\begin{array}{l}\text { Waipaoa river, } \\
\text { New Zealand }\end{array}$ & 4.4 & 2150 & $10^{4} \sim 10^{5}$ & $\begin{array}{l}\text { Crosby and } \\
\text { Whipple, } 2006\end{array}$ \\
\hline $\begin{array}{l}\text { Tech messinian } \\
\text { river }\end{array}$ & $0.08-0.25$ & 800 & $10^{5} \sim 10^{6}$ & this study \\
\hline $\begin{array}{l}\text { Tet messinian } \\
\text { river }\end{array}$ & $0.13-0.4$ & 1400 & $10^{5} \sim 10^{6}$ & this study \\
\hline $\begin{array}{l}\text { Durance } \\
\text { messinian river }\end{array}$ & $0.33-1$ & 12000 & $10^{5} \sim 10^{6}$ & this study \\
\hline $\begin{array}{l}\text { Rhone } \\
\text { messinian river }\end{array}$ & $1-5$ & $10^{5}$ & $10^{5} \sim 10^{6}$ & this study \\
\hline $\begin{array}{l}\text { Nile messinian } \\
\text { river }\end{array}$ & $3.3-20$ & $3.10^{6}$ & $10^{5} \sim 10^{6}$ & this study \\
\hline $\begin{array}{l}\text { Niagara falls, } \\
\text { North America }\end{array}$ & 1.5 & $7.10^{5}$ & $10^{4}-10^{5}$ & Wohl, 1998 \\
\hline $\begin{array}{l}\text { Kauhao river, } \\
\text { Hawaï }\end{array}$ & $10^{-3}$ & 50 & $10^{6} \sim 10^{7}$ & Seidl et al., 1994 \\
\hline $\begin{array}{l}\text { Parachute creek, } \\
\text { Colorado basin }\end{array}$ & $3.75 .10^{-3}$ & $5.10^{2}$ & $10^{6} \sim 10^{7}$ & $\begin{array}{l}\text { Berlin and } \\
\text { Anderson, } 2007\end{array}$ \\
\hline $\begin{array}{l}\text { Roan creek, } \\
\text { Colorado basin }\end{array}$ & $6.25 .10^{-3}$ & $1.3 .10^{3}$ & $10^{6} \sim 10^{7}$ & $\begin{array}{l}\text { Berlin and } \\
\text { Anderson, } 2007\end{array}$ \\
\hline $\begin{array}{l}\text { Tinguiririca river, } \\
\text { Andes }\end{array}$ & $0.01-0.04$ & $1.8 .10^{3}$ & $10^{6}-10^{7}$ & Farias et al., 2008 \\
\hline $\begin{array}{l}\text { Shoalhaven } \\
\text { river, Australia }\end{array}$ & $5.10^{-3}$ & 6920 & $10^{6} \sim 10^{7}$ & $\begin{array}{l}\text { Young and } \\
\text { McDougall, } 1993\end{array}$ \\
\hline $\begin{array}{l}\text { Macquarie river, } \\
\text { Australia }\end{array}$ & 0.0167 & 26000 & $10^{6} \sim 10^{7}$ & $\begin{array}{l}\text { Tomkins and } \\
\text { Hesse, } 2004\end{array}$ \\
\hline $\begin{array}{l}\text { Susquehanna } \\
\text { river, } \\
\text { Appalachian }\end{array}$ & 0.04 & 62000 & $10^{6} \sim 10^{7}$ & $\begin{array}{l}\text { Pazzaglia et al., } \\
1998\end{array}$ \\
\hline
\end{tabular}

Table 2

Compilation of different migration rates of knickpoint (see also Figure 5) 